УдК 7.03

\title{
Т.Н. Красавченко ${ }^{\odot}$
}

\section{РУССКИЕ СЕЗОНЫ ДЯГИЛЕВА В ВЕЛИКОБРИТАНИИ. ПАРАДОКСЫ КУЛЬТУРНОГО ВЗАИМОДЕЙСТВИЯ}

Аннотащия. Со второй половины XIX в. в России существовал культ балета, тогда как в остальной Европе к нему относились как к «недоискусству». В начале XX в. со сменой мировоззренческой и эстетической парадигм мейнстримом постепенно становится модернизм, в Европе назревает необходимость радикальной реформы искусства вообще и балета в частности. Наиболее мощный и яркий его реформатор - Сергей Дягилев, харизматичная личность с редким организаторским талантом и поразительным эстетическим чутьем, прошедший «школу» русского Серебряного века, прежде всего «Мира искусства», модернист и позже авангардист. С 1909 г. он стал «экспортером» русского искусства в страны Запада. Парадокс в том, что именно в Великобритании, по своей традиционалистской, умеренной, гибко консервативной культуре противоположной России и авангардистскому артистическому темпераменту Дягилева, его труппа в большей мере, чем в других странах, нашла признание. Оставаясь «другими» в сдержанной регламентированной Великобритании, они тем не менее существенно дополнили «дефициты» британской культуры, многое сде-

(C) Красавченко Т.Н.

DOI 10.31249/hoc/2019.01.03 
лав для нее, без чего она была бы другой, возможно, гораздо беднее. Дягилев вошел в британский инонациональный Пантеон.

Ключевые слова: русский балет; английская культура; культурное взаимодействие; традиционализм; консерватизм; модернизм; авангардизм; инонациональный Пантеон.

\section{Tatiana Krasavchenko Russian seasons in Great Britain. Paradoxes of cultural interaction}

Abstract. Since the second half of the XIX ${ }^{\text {th }}$ century one may talk of the ballet cult in Russia, while in the rest of Europe it was perceived not quite as an art. At the beginning of the XXth century while outlook and aesthetics in Europe change, and modernism step by step became the ideological mainstream, the radical reform of art, and ballet in particular, became necessary. The most powerful and bright its reformer is Serge Diaghilev, charismatic person of a rare organizational gift and a striking aesthetic intuition, modernist and later avangardist, formed by Russian Silver Age, first of all by «The World of Art». Since 1909 he became an «exporter» of Russian art to the West. The paradox is that the modernist, avangardist Diaghilev and his troupe found recognition in Britain, which by its traditionalist, moderate, conservative cultural paradigm was an antipode to Russia, more than in other countries (even than in France). Diaghilev was «different», «an outsider» in the restrained Great Britain but nevertheless he with his troupe considerably filled in the «gaps» in British culture and did much for it; without them it might be different, probably, much poorer. Diaghilev became a part of a British foreign Pantheon.

Keywords: Russian ballet; English culture; cultural interaction; traditionalism; conservatism; modernism; avangardism; foreign Pantheon.

Дягилев понимал специфику консервативной британской культуры и публики, поэтому история «Русских сезонов» в Лондоне началась в 1911 г., на два года позже, чем в Париже: сначала был нужен, как говорят в Британии, «континентальный» успех. После триумфа в парижском театре «Шатле» Дягилев и его труппа приехали в Лондон уже как знаменитости. Среди британских меценатов, помогавших ор- 
ганизовать гастроли в Лондоне, были леди Глэдис Рипон ${ }^{1}$, по словам ее друга О. Уайльда, в обществе высокородная «важная леди, а в душе богема, жаждавшая поразительного» (12, p. 180); леди Оттолайн Моррелл, своя среди писателей и художников-модернистов группы «Блумсбери»; сэр Джозеф Бичем, миллионер-фармацевт, потративший целое состояние на карьеру своего сына - дирижера Томаса Бичема и «Русские сезоны» (14, р. 279).

Британская пресса откликнулась сразу на первое же выступление труппы Дягилева в Лондоне 21 июня 1911 г. в Королевском оперном театре Ковент-Гарден - с одноактными балетами в постановке Михаила Фокина - «Павильон Армиды» Н. Черепнина, близкого Дягилеву еще по «Миру искусства» с либретто (по новелле Т. Готье) и декорациями А. Бенуа; «Карнавал» Р. Шумана (в оркестровке Н. РимскогоКорсакова, А. Лядова, А. Глазунова, Н. Черепнина, декорациями и костюмами Л. Бакста); с половецкими плясками из оперы Бородина «Князь Игорь». «Когда в “Павильоне Армиды”, - писала “Дейли Ньюс" (22.6.1911), - оркестр заиграл прелюдию (дирижировал композитор), зрители удивленно переглянулись. Вместо бренчащих мелодий, обычно принятых в балете нашей страны, они услышали чудесную игру, беспокойную, страстную, временами пронзительную, способную быть прелюдией к серьезной опере. Это значило, что в России балет - серьезная форма искусства, а не фривольный повод показать хорошеньких девушек и наряды. Сцена обворожительна. <...> по сочетанию изысканных красок, грациозности движений, живой и небанальной музыке - по артистизму и очарованию спектакль превосходит все когда-либо показанное в этой стране». В «Таймс» (22.6.1911), где рецензии тогда были анонимными, критик (возможно, драматург и журналист Джордж Кальдерон, знаток России, первый в Великобритании переводчик «Чайки» Чехова) писал: «Уже несколько лет очевидно, что русские - лучшие в мире танцоры. <..> Шумановский "Карнавал" - сплошная радость от начала до конца. <.. > Сценическая организация спектакля (термин “хореография" тогда еще не вошел в

${ }^{1}$ В ее родословной - Екатерина Воронцова, дочь русского посла в Британии Семена Романовича Воронцова (1744-1832), в 1808 г. вышедшая замуж за Джорджа Герберта, 11 графа Пемброка. 
оборот. - Т. К.) поражает небывалым артистизмом» (14, р. 205). В «Дейли Мейл» (23.6.1911) музыкальный критик Ричард Кэпелл назвал спектакль «чуть меньше, чем откровение», и там же (26.6.1911), рецензируя фокинский балет «Виде́ние розы» на музыку К.-М. фон Вебера по стихотворению Готье, писал об «изысканности» Карсавиной и «волшебной грации прыжков Нижинского, предполагающей всю нерастраченную радость молодости». Газета «Обсервер» (25.6.1911) увидела в балете «мечту о совершенной красоте (курсив мой. - T. К.), слишком быстро заканчивающуюся». Дж. Кальдерон («Таймс», 24.6.1911) отметил «новое и поразительное наслаждение, доставляемое новаторской художественной формой» балетов (курсив мой. - Т. К.), <..> “Карнавал" - изысканно тонкое художественное целое $<\ldots>$, где нет ни одной лишней детали. <..> Именно все детали в сумме дают, в конце концов, совершенно новое и блестящее восприятие произведения Шумана. <..> Это невероятно серьезное Искусство, но ни в коем случае не серьезнее, чем Жизнь (курсив мой. - T. К.)». Тут важно, что британские критики сразу заметили в дягилевском балете признаки высокого искусства: «мечту о совершенной красоте», т.е. жажду утопии, поразительную «новаторскую художественную форму», «серьезность», важную для англичан, утверждавшуюся еще Мэтью Арнольдом, но при этом в характерно британском духе высшим мерилом оставалось понятие «жизнь».

После коронации Георга V в Вестминстерском аббатстве 22 июня 1911 г. согласно программе торжеств 26 июня состоялся (неслыханное для Британии событие) гала́-концерт труппы Дягилева в КовентГарден (это произошло главным образом благодаря леди Рипон) (14, р. 207). В зале, украшенном 100 тыс. роз (в основном искусственных из-за боязни дурмана живых роз) царило волнение (14, р. 208). Однако аплодисментов, обычных в паузах между танцами, не было, хотя король назвал представление «великолепным» (Royal archives), а королева Мария записала в дневнике: «И музыка, и балет очень хороши» (ibid.). Но на взгляд Дягилева, их приняли холодно: хотя «Дейли Мейл» писала: «Восхищение очаровательной мадам Карсавиной нарастало. Нижинский казался воплощением юношеской радости» (27.6.1911), никто из них не вызвал аплодисментов. Лишь после танца шутов раздался странный приглушенный звук: такова была британ- 
ская специфика - «в присутствии короля аплодисменты ограничивались, и для партера были обязательны лайковые перчатки» (14, p. 208).

Настоящим откровением стали впервые показанные в Лондоне на следующий день оформленные А. Бенуа «Сильфиды» («Шопениана») новый тип бессюжетного балета реформированной Фокиным классической школы $(5$, с. 82). «Как много выигрывает знакомая музыка, когда преподносится в оболочке очаровательного балета!» - писала «Дейли Телеграф» (28.6.1911). «Любители музыки, - заметил Р. Кэпелл, смотрят косо на “свободное обращение” с бессмертными шедеврами прошлого, <..> но когда невесомая Карсавина летает по сцене, они полностью побеждены» (Daily Mail, 1911, 28.6). Среди лондонских постановок не было балетов Стравинского, пока «слишком смелых для англичан» (1, с. 58-59). Достаточно того, что «Половецкие пляски», где хореография Фокина и декорации Рериха соответствовали буйно-красочной музыке Бородина и «варварская» неистовая стихийность дикой орды органично сочеталась с ориентальной экзотикой, ошеломили англичан, и зрители, правда, в основном пожилые дамы, покидали зал. Многое в русском балете казалось англичанам скандальным (вакхизм, любовные шашни черных рабов и белых женщин в «Шехерезаде», яркие контрасты дизайна Бакста) и одновременно поразительным: мужской танец на первом плане - после монополии прима-балерин в балете XIX в., высокий уровень кордебалета (5, с. 83).

Дирекция Ковент-Гарден пригласила труппу на осенний сезон (16 октября - 9 декабря) 1911 г. В нем участвовали звезды Императорского балета А. Павлова, Т. Карсавина, М. Кшесинская. Тут Дягилев переоценил «консерватизм» англичан. Подобно французам, они сочли «Жизель» скучной, как и «ужатое» до двух актов «Лебединое озеро», которое Дягилев не решился дать в Париже, учитывая нелюбовь французов к Чайковскому (1, с. 61). Ни Карсавина, ни Павлова, ни Нижинский не смогли искупить «слабости» «Жизели». «Дейли Ньюс» (30.10.1911) писала: «Необычайная интенсивность игры мадам Павловой в сцене сумасшествия придала спектаклю драматизм, но он был чужеродным среди вежливых условностей остального». По мнению критика из «Таймс» $(30.10 .1911)$, в «Жизели» и «Клеопатре», где Павлова танцевала с Нижинским, ей «не удалось развернуться». 11 ноября она станцевала с Нижинским знаменитое па-де-де Чайковского и Пе38 
типа (14, p. 211) и покинула труппу Дягилева: ее не устраивала хореография Фокина - сочетание классического танца с непривычным, сложным мимическим рисунком, новшества современной музыки; она предпочитала одухотворенный классический танец и создала свою труппу. Что касается Кшесинской, то русские - Дягилев и Григорьев сочли ее выступление триумфом, тогда как британские газеты писали: не знай публика, что Кшесинская - богатейшая балерина, владелица огромных сапфиров, ее сочли бы профессиональной танцовщицей обычного уровня (Daily News, 15.11.1911). «Ей не свойственно утонченное вдохновение, присущее Павловой» (Daily Mirror, 16.11.1911). Но в целом «Русский балет» произвел глубокое впечатление. После последнего выступления в 1911 г. художник Чарльз Рикеттс, лучший (наряду с Обри Бердслеем) иллюстратор книг Уайльда, писал другу: «Мне горько < ..> русские покинули нас! <..> В последний вечер они танцевали, как в раю - Карсавина обесценила бриллианты, подаренные царем ее сопернице (забыл ее имя), а Нижинский просто не прикасался к земле и смеялся над нашими печалями и страстями где-то в воздухе. < ..> “Карнавал”, “Сильфиды” и "Виде́ние” вызвали оглушительные аплодисменты, но “Шехерезада” ошеломила. <...> Они делают смерть прекрасной, и мы влюбляемся в нее <...>». Когда оркестр сыграл гимн «Боже, храни короля», означавший: пора на выход, Рикеттс, «бледный от гнева», изо всех сил закричал: “Карсавина!”, последовала пауза, галерка зашумела $<\ldots>$, и зал двадцать минут аплодировал» (33, р. 195). Р. Кэпелл подтвердил это в «Дейли Мейл» (11.12.1911).

К третьему лондонскому сезону (12 июня - 1 августа 1912 г. в театре Ковент-Гарден) у труппы Дягилева возник круг поклонников. Рикеттс писал поэту Гордону Боттомли, что он и его друг, художник Чарльз Шэннон, с нетерпением ждут русских: «Они олицетворяют собою страсть. <..> Все, что в древнем мире говорилось о знаменитых танцорах, соблазнявших императриц и пр., - истинная правда. Нижинский превосходит по страсти, красоте и магнетизму даже Карсавину, а она - Муза, или воплощение нескольких Муз - Меланхолии и Причуды, способная передать трагедию <.. > необузданность девственности и яд желания; она - совершенный инструмент, выражающий любую эмоцию. А Нижинский - это живое пламя, сын Гермеса» (33, p. 176-177). Для Рикеттса, которого Р. Бакл назвал «эстетическим ка- 
мертоном» (14, р. 232), энергетика страсти, излучаемая русскими танцорами, - явно позитивный феномен.

В программу сезона вошли фокинские одноактные балеты - «Жарптица» И. Стравинского, «Тамара» М. Балакирева, «Нарцисс» Н. Черепнина, который в Лондоне приняли лучше, чем в Париже. «Таймс» (10.7.1912) писала: вакханки и «ничем не замутненная радость первых танцев Нарцисса» «столь же захватывающи, как и все, что дарят нам русские». Р. Кэпелл сделал важное обобщение: русские показали, как три «вида искусства: музыка, живопись и танеи - на максимуме своих возможностей - создают несравненный спектакль (курсив мой. - T. К.)» (Daily Mail, 13.6.1912).

Но не все в Лондоне восхищались балетами Дягилева. Критика пуританского толка возрождала стереотип о варварстве русских. Лондонская «Пэлл Мэлл Газет» (13.6.1912) назвала «Тамару» - «бесконечной оргией извращенного желания»: «Музыка Балакирева богата варварским колоритом (курсив мой. - T. К.), она достигает уровня страсти (курсив мой. - T. К.)», тут «страсть»- падение. Но для молодого англичанина Сирила Бомонта дягилевский балет стал судьбоносным $^{2}$.

Критика ранних «Русских сезонов» была в основном вкусовой, импрессионистичной, но уже тогда сознавался глубокий смысл деятельности Дягилева. Летом 1912 г. поэт Руперт Брук сказал знакомой актрисе после спектакля в Ковент-Гарден: «Вы понимаете, что видели чудо?» (цит. по: 14, р. 236), и, ощутив масштаб и потенциал Дягилева и его проекта как «красоты, способной спасти мир», писал о русских Эдварду Маршу, личному секретарю Черчилля и покровителю авангардного искусства, положительно отзывавшемуся о «Русских балетах» в британской периодике: «Они, как никто иной, способны спасти

${ }^{2}$ К 1920 г. книжный магазин Бомонта в театральной зоне Лондона на Черринг Кросс-роуд, 75 стал центром любителей балета; основав в 1917 г. издательство «Бомонт пресс», С. Бомонт публиковал в нем книги о балете, среди них и свои собственные - о Лидии Лопуховой (1920), другом которой он стал, учебник (вместе со Станиславом Идзиковским) о системе обучения Энрико Чекетти (1922), историю балета в России (1613-1881) (1930), книгу об Анне Павловой (1932), «Michel Fokine and his ballets», 1935; «Vaslav Nijinsky», 1932; краткую историю балета (1933), «The Diaghilev ballet in London» и др. - L.: Putnam, 1940 (14, p. 230 а.o.). 
нашу цивилизацию. Отдал бы все, чтобы стать балетным дизайнером» $(26$, р. 75), имея в виду, что хотел бы в искусстве быть личностью масштаба Дягилева (14, p. 236).

Во время четвертого лондонского сезона (4 февраля - 7 марта 1913) в Ковент-Гарден Дягилев, подготавливая лондонскую публику к «Весне священной» Стравинского, показал «Петрушку» (хореография М. Фокина, декорации и костюмы А. Бенуа), вызвавего, как заметил С. Бомонт, изумление зрителей; он и сам, сначала подумав, что музыка «немыслимо дерзка и неотесанна», вскоре поддался ее обаянию (13, p. 42). «Таймс» отозвалась о балете как об «освежающе новом и освежающе русском» (5.2.1913), а писатель Осберт Ситвелл назвал создателей «Петрушки» «гениальными», а позднее пришел к выводу, что сюжет был пророческим для судьбы европейцев (35, р. 242).

«Послеполуденный отдых фавна» Дебюсси в постановке Нижинского, который даже в Париже сочли слишком эротичным и «аморальным» (1, с. 68), на первом показе в Лондоне 11 февраля 1913 г. вызвал шиканье, но возобладали аплодисменты, и балет пришлось повторить. «Таймс» (18.2.1913) объявила наступление «нового этапа»в искусстве балета.

После скандала парижской премьеры «Весны священной» 29 мая 1913 г. Дягилев сначала во время летнего лондонского сезона (24 июня - 25 июля) в Королевском театре Друри-Лейн показал русскую оперу: «Бориса Годунова» и «Хованщину» Мусоргского, «Ивана Грозного» («Псковитянка») Римского-Корсакова. Шаляпин, «с трепетом в душе» ехавший в Лондон, опасаясь, что «русская музыка, русские оперы едва ли будут поняты англичанами» (8, т. 1, с. 189), имел триумфальный успех.

Но «Весна священная» казалась слишком большим испытанием для британцев. Несмотря на привлекательность «русской тематики», в ней были нарушены все нормы романтической красоты и благозвучия, хореография ошеломляла, в ритуальных кровавых жертвоприношениях во имя жестоких богов таилось предчувствие великих социальных потрясений $(2$, с. 108, 111). Эксперименты Нижинского в «Весне...» в известной мере были параллельны исканиям русского авангарда: Маяковского и Хлебникова в поэзии, Стравинского и Прокофьева в музыке, художников «Бубнового валета» в живописи, в его пластике находили отголоски полотен Гогена, Матисса $(2$, с. 103, 105). Как реа- 
гировали британцы на взрывную силу «антиэстетизма» балета? Английский оркестр отказался репетировать (14, p. 257). Накануне премьеры (10.7.1913) приятельница Дягилева Мися Серт-Эдвардс писала из Лондона Стравинскому: «Оркестр устроил большой скандал», но уже 12 июля телеграфировала ему: «Полный успех» (цит. по: 14, p. 258), хотя, по мнению Бакста, показанная в Лондоне четыре раза «Весна...» «была принята двойственно» (там же), но все-таки к ней отнеслись лучше, чем в Париже. Возможно, в Британии сработала «привычность» для британцев стереотипного представления о русских как о «полуазиатах, полуевропейцах», не тронутых викторианской «суперцивилизацией». Однако британские критики концентрировались на модернистской, асимметрично ритмизированной музыке балета. Для автора книги «Искусство Нижинского» (1913) Джеффри Уитворта откровением стала хореография Нижинского; «Весна...», в которой нет «почти всех привычных в балете признаков красоты», показалась ему «новым этапом в балете», и более того - в искусстве; постимпрессионизм Стравинского он расценил не как «разрушение того, что ценилось в прошлом $<\ldots>$, а как постепенную эволюцию к новой экспрессивности и технике» $(40$, p. 82, 98-99). Леонард Инкстер увидел в балетах Нижинского шаг вперед по сравнению с хореографией Фокина: «Здесь больший синтез <музыки и хореографии>, они не служат друг другу, а выражают одну идею» (цит. по: 18, р. 317).

В 1914 г. 30 мая - 25 июля по договоренности с сэром Джозефом Бичемом в театре Друри-Лейн вновь состоялся оперно-балетный сезон. В «Борисе Годунове» Мусоргского и «Князе Игоре» Бородина с успехом пел Шаляпин. Томас Бичем, дирижировавший «Князем Игорем», писал о «русском характере»: «Для меня (т.е. англичанина, привыкшего к четкому графику работы и - шире - жизни. $-T$. К.) до сих пор загадка, как мы дожили до премьеры <8 июня 1914 г.>. Несколько дней перед ней напоминали больше железнодорожную станцию, чем театр - с трех или четырех сторон прибывали декорации. <...> Оркестр играл с ошибками. <...> Ведущие певцы ссорились между собой $<\ldots>$ генеральная репетиция началась вскоре после полудня, продолжалась до рассвета $<\ldots>$ и закончилась только потому, что с дирижером <Эмилем Купером> случилась истерика. <.. > Стало ясно: спектакль не может быть готов к сроку; и все же такова особенность этих замечательных людей, пятнадцать часов спустя все встало на свое ме42 
сто <..> и спектакль получился столь же безупречный, сколь и живой. Правда, во время первого акта декорации для последнего акта еще дописывались художниками, но когда все было закончено, осталось еще не менее получаса...» (11, p. 183-184).

После разрыва с Нижинским (в декабре 1913 г.) Дягилеву в летнем сезоне 1914 г. пришлось временно вернуть Фокина, и в Лондоне бо́льший триумф, чем в Париже, имела опера-балет «Золотой петушок» Римского-Корсакова в оформлении Н. Гончаровой. После первого показа 15 июня 1914 г. Ч. Рикеттс записал в дневнике: «В невероятном восторге. <..> Музыка тонкая, завораживающая и оригинальная; идея разместить певцов по обе стороны сцены, как в оратории, а в центре - пантомиму и танцы - восхитительна. <..> Танцы и мимика Карсавиной $<\ldots>$ несравненны, как и интеллектуальность организации спектакля и хореографической изобретательности» (33, р. 139). Сезон стал триумфом Фокина, в репертуаре труппы было не менее 15 его балетов (1, с. 93-94).

Война завершила этап Фокина - Нижинского в истории дягилевского балета. После того как Россия, бросив западных союзников, заключила с Германией сепаратный мир, она превратилась «в общественное пугало, отбрасывающее тень на все, имевшее к ней отношение» (36, р. 24). Труппа Дягилева оказалась в трудной ситуации. Весной 1918 г. она была в Лиссабоне, затем в Испании. Возвращение в Париж, внезапно ставший «антирусским», было невозможно (3, c. 357). И тут последовало спасительное предложение из Лондона: контракт на сезон 5 сентября 1918 г. - 29 марта 1919 г. в Колизее (мюзик-холле на 2359 мест), рассчитанном на широкую публику. Возможно, Дягилев испытал унижение от «смены площадок», но новая публика спасла его театр (14, p. 346). «Русские балеты» давали 12 спектаклей в неделю, участвовали в дневных и вечерних программах мюзик-холла. Хореографом стал Леонид Мясин. Газета «Обсервер» (11.9.1918) назвала его первый балет - «Женщины в хорошем настроении», показанный 5 сентября 1918 г. и ознаменовавший собою еще одно новое направление в хореографии (1, с. 122), не только «блестящим произведением искусства, но и волнующим развлечением» (цит. по: 14, p. 347). Для С. Бомонта, «привыкшего к сладостной печали Карсавиной», неожиданностью стала «прирожденная комедиантка» Лидия Лопухова (13, p. 108, 109); как писал журнал «Дансинг Таймс» 
в ноябре 1918 г., она танцует «как менада и электризует публику абсолютной радостью и безграничной живостью движений» (цит. по: 14, p. 348). Критики беспокоились, как шумная, грубоватая мюзикхолльная публика воспримет дягилевский балет, но в неизменно полном зале (1, p. 122) «царила полная тишина. Друри-Лейн и КовентГарден не могли вести себя лучше» (The Times, 6.9.1918).

«Ballets Russes» стали принимать в Англии лучше, чем во Франции. Дягилев тоже стал внимательнее к Англии. В частности, в сезоне 30 апреля - 30 июля 1919 г. в театре «Альгамбра» состоялась премьера «актуального», поразившего британцев балета (14, р. 351) «Лавка чудес» Дж. Россини (в обработке О. Респиги), где две куклы (одну из них танцевала Лопухова) сбегают из викторианского (что символично) магазина игрушек. Занавес, расписанный Андре Дереном в постимпрессионистской манере на сюжет из XIX в. (перекликавшийся с непочтительными биографиями «Выдающихся викторианцев» блумсберийца Литтона Стрейчи), британские модернисты восприняли как «знамя постимпрессионизма» $(14$, p. 355$)$, а спектакль как откровенное признание эстетической близости им русского балета. На премьере 5 июня был аншлаг, публика стояла в проходах (13, р. 134-136), а во время зажигательного канкана Мясина и Лопуховой, превратившейся из фарфоровой куклы в вакханку, «скандировала их имена» (26, р. 146). Миф о «холодной британской публике» развеялся.

В сезонах 29 сентября - 20 декабря 1919 г. в Театре Эмпайр и 10 июня - 30 июля 1920 г. в Ковент-Гарден имел успех одноактный «неклассицистский» балет Стравинского - «Пульчинелла» (хореограф Мясин, художник Пикассо) по мотивам музыки Галло, Перголези и др. композиторов XVIII в. (14, р. 361). Однако у «Русского балета» были свои антагонисты, и, возможно, самый последовательный из них музыковед Эрнест Ньюмен назвал «Весну священную», показанную 27 июня 1921 г., «самым глупым, скучным спектаклем», когда-либо им виденным (Sunday Times, 3.7.1921) (14, p. 386), тогда как Т.С. Элиот восхищался музыкой Стравинского, напоминавшей дух «первобытного ритуала» и в то же время очень современной (16, p. 452). Нет ничего удивительного в том, что именно Стравинский, самый радикальный из русских композиторов той поры, - главное открытие Дягилева (в известном смысле его alter ego), стал мишенью консерваторов. После показа «Свадебки» в летнем сезоне (14 июня 44 
23 июля 1926) в Театре Его Величества (14, р. 470) Ньюмен постарался в клочья разорвать Стравинского: «Теперь каждый понимает, кто он и кем всегда был - Малым Мастером, который на год или два поднялся до уровня гения, потом опустился до уровня таланта, затем посредственности, а теперь ничто...» (Sunday Times, 20.6.1926). В защиту выступил Г. Уэллс: «Не знаю другого столь же свежего и захватывающего балета. Хотел бы вновь и вновь смотреть его и протестую против заговора упрямой глупости, который может привести к исключению балета из программы». Уэллса восхитили «изображение серьезности, простодушия, хитроватости крестьянской души, сочетание торжественности с юмором» и решительный отказ от «красивой традиции пейзанства эпохи Ватто - Фрагонара» (цит. по: 24, р. 327; 22, p. 190). А Дягилев, игнорируя нападки на Стравинского, в сезоне 13 ноября - 11 декабря 1926 г. возобновил в театре «Лицей» (3 тыс. мест) «Жар-птицу» Стравинского с Лопуховой, новой сценографией Н. Гончаровой и костюмами Веры Судейкиной (14, р. 473). «Таймс» (26.11.1926) назвала балет «одним из самых прекрасных спектаклей труппы».

Дягилев, продолжая свое движение к новому, представил британцам композитора иного, чем Стравинский, направления. Юмористический балет Прокофьева «Сказка про шута, семерых шутов перешутившего» по мотивам уральской сказки приняли двойственно. «Таймс» писала о нем как о «расхлябано-импровизированной шараде» (10.6.1921), Э. Ньюмен сравнил его музыку с «уличным шумом» (Sunday Times, 12.6.1921). Тогда как, по словам Р. Кэпелла, «передовой Лондон» радовался (Daily Mail, 10.6.1921), и балет объявили «откровением музыкального гения» (4, с. 205). Дягилев 18 июня 1921 г. саркастически отчитал Ньюмена в газете «Дейли телеграф»: «Бедный старина, несите с достоинством свой возраст и не вставайте в ряды тех, кто вызывал смех, освистывая премьеру “Кармен”, полотна Мане или поэзию Малларме. Очень легко понять, что с “Шутом” происходит то же самое...» (6, т. 1, с. 242-243). Выразительная «имагологическая» деталь: на генеральной репетиции 8 июня 1921 г. «Прокофьев из-за жары снял пиджак, и многие леди в ужасе бежали» (22, p. 160).

Решив, что наступило время возродить традиции классики, Дягилев на сцене «Альгамбры» в сезоне 2 ноября 1921 - 4 февраля 1922 г. представил «Спящую красавицу» Чайковского с хореографией 
М. Петипа, переименованную в «Спящую принцессу», с некоторыми коррективами в партитуре и исключением нескольких эпизодов (19, p. 178). «Дейли Экспресс» (3.11.1921) писала: «Тальони могла бы позавидовать овациям Лопуховой $<\ldots>$ танцоров вызывали около пятидесяти раз». Но интеллектуалы «Блумсбери» сочли спектакль «старомодным» (14, p. 392). Дягилев, видимо, не учел того, что уже «приучил» лондонских зрителей к одноактным балетам, полнометражный балет казался растянутым. Э. Ньюмен злорадно писал о «самоубийстве Русского балета» (Sunday Times, 6.11.1921) и своевременности вышедшей в Лондоне книги У.А. Пропета (32) «Русский балет в Западной Европе» (1921): «Никто не пишет биографию живых, а "Русский балет", если и не мертв, то умирает» (Sunday Times, 31.7.1921). На самом деле Дягилев опередил свое время: в 1930-е годы, казалось бы, столь «неуместная» постановка «Спящей красавицы» 1921 г. сыграла важную роль в развитии британского балета, классика XIX в. заняла в его репертуаре прочное место.

Однако после 1921 г. почти три года в Лондоне не было «Русских сезонов», а затем в Колизее - сразу три: 24 ноября 1924 - 10 января 1925 г., 18 мая - 1 августа, 21 декабря - 6 января 1926 г. Британские газеты приветствовали его возвращение; в Daily Herald (25.11.1924) статья называлась «Старые фавориты и новое появление». Общее мнение лондонской прессы: русские стали лучше, чем прежде (Sunday Express, 5.7.1925). Дягилев вновь почувствовал себя в Лондоне уверенно. И в программе сезона 13 июня - 23 июля 1927 г. в Театре принца Уэльского пошел на риск - показал балет на советскую тематику - «Стальной скок» (музыка С. Прокофьева, оформление Г. Якулова), где Мясин выступил в роли молодого рабочего, чьи «напряженные движения передавали славянский темперамент и конфликт между личной жизнью и преданностью родине» (14, p. 172). На лондонской премьере 7 июля Дягилев, готовый к неприятностям в «антибольшевистском Лондоне», сел в оркестровую яму с револьвером в кармане - на случай эксцессов, но все обошлось; правда, к концу спектакля публика с тревогой поглядывала на ложу герцога Коннаутского, кузена царицы, но он зааплодировал, и аплодисменты публики перешли в овацию. Дягилев выбрался из оркестровой ямы, озадаченный непредсказуемыми англичанами (19, р. 246, 247). 
В 1920-е годы Дягилев, возможно, как знак благодарности Британии, поставил три балета на английские сюжеты, хотя до тех пор особых надежд на английских композиторов не возлагал (14, p. 460). Первым был «Ромео и Джульетта» (1925) Константа Ламберта, студента Королевского колледжа музыки. Он попросил Дягилева прослушать музыку к его балету «Адам и Ева». Тот признался, что «не любит английскую музыку», но балет ему понравился, хотя он заменил название на «Ромео и Джульетта» (15, p. 172-173). Музыка Ламберта, со следами влияния Стравинского и модной парижской школы, была многообещающей, искусной, но малооригинальной (14, p. 470). Вероятно, Дягилев хотел компенсировать это оригинальностью оформления, и тут сразу возникли расхождения. Ламберт предпочитал валлийского художника-постимпрессиониста Огастеса Джона или же британского авангардиста, вортициста Уиндема Льюиса (14, p. 466); Дягилеву их работы не понравились, и он даже хотел обойтись без декораций, ибо спектакль был задуман как репетиция балета по пьесе Шекспира, но Ламберт обиделся. Тогда Дягилев заказал оформление Максу Эрнсту и Хуану Миро, создав, таким образом, «конфликт» между умеренной музыкой и ультрасовременным оформлением. В конце балета Ромео и Джульета улетали на аэроплане в кожаных костюмах, кепках и защитных очках. Ламберт был во всем не согласен с Дягилевым. Русские вообще шокировали его: сцена криков и почти кулачной ссоры опоздавшего на репетицию танцора Славинского вызвала у него почти обморок $(37$, p. 243, 244). После парижской премьеры балета (хореография Б. Нижинской) 18 мая 1926 г. Ламберт писал матери: «Для оформления балета Дягилев выбрал двух художников десятого сорта из психически ненормальной группы “сюрреалистов”. < ..> Более того, он внес позорные изменения в хореографию...» (цит. по: 34, р. 56). «Таймс» отметила, что музыка Ламберта «чужда балету» (22.6.1926). Прокофьев писал Асафьеву: «Балет плох, русское влияние не спасло» (цит. по: 4, с. 174).

3 декабря 1926 г. в «Лицее» состоялась премьера балета «Триумф Нептуна» (хореограф Г. Баланчин) британского композиторамодерниста Лорда Бернерса (Джералд Тирвит, 1883-1950). В этом балетном парафразе старинной английской пантомимы (с декорациями Александра Шервашидзе по старинным английским гравюрам (14, 
p. 473)) использовались фольклорные жанры (жига, контрданс и др.), и трудно было отличить, где лирика, где карикатура (5, с. 174). Р. Бакл считал успех «Нептуна» триумфальным (14, р. 478), тогда как русский музыковед и композитор Леонид Сабанеев писал: «Музыка, что греха таить, просто плохая, но это вообще в традициях англичан, которые, как известно, очень любят музыку, но музыка их не любит» (цит. по: 5, c. 174).

В 1928 г. в Театре Его Величества (сезон 25 июня - 28 июля) 16 июля британцы увидели балет «Нищие боги» - пастораль на музыку Г.Ф. Генделя - в обработке Т. Бичема (хореограф Г. Баланчин, художники Л. Бакст, Х. Грис; дирижер Т. Бичем). Дягилев мало ждал от этого спектакля и даже использовал старые декорации и костюмы, но Баланчин создал такие очаровательные танцы, что критики признали: Томас Бичем и «Русский балет» заслуживают «овации». По мнению Р. Бакла, популярность балета вышла за рамки Англии (14, p. 505).

Очевидно, что мнения британских и русских критиков о дягилевских английских балетах расходились. Обращение Дягилева к не очень значительному английскому репертуару отчасти объясняли и его вынужденной (оказавшейся унизительной) материальной зависимостью от газетного магната лорда Ротермира (14, p. 463-464).

$$
* * *
$$

Суть наблюдавшегося культурного взаимодействия раскрывает пьеса «Правда о русских танцорах» (The Truth about the Russian Dancers, 1920) Джеймса Мэтью Барри (1860-1937), известного шотландского драматурга и романиста, автора произведений о Питере Пэне, мальчике, отказывавшемся взрослеть. Барри написал пьесу для Тамары Карсавиной. Премьера состоялась 15 марта 1920 г. в лондонском Колизее. Автором сатирической с эксцентричными танцевальными ритмами и лирическими мотивами музыки к пьесе был ценимый Дягилевым британский композитор Арнольд Бакс (14, p. 360-361). Пьеca, как отмечает Ольга Соболева (Лондонская школа экономики и политических наук), была и искусной пародией на повальное увлечение Русскими сезонами, и оригинальным художественным произведением (36). О значении пьесы для Барри свидетельствует 14 ее версий, его участие в репетициях, внезапные изменения в либретто, чем он «сводил с ума» актеров. 
Действие пьесы происходит в британском замке Вир, древнем оплоте традиционных ценностей, куда внезапно врывается Кариссима, русская балерина (ее играет Карсавина), выражающая себя языком танца и мимики, более выразительным, чем язык обычной речи. Так исключается проблема «языкового барьера». Леди Вир и Билл, ее пожилой зять (игрок, плут, негодяй), шокированы, а молодой лорд Вир влюбляется в неотразимую танцовщицу и женится на ней. Согласно Маэстро, управляющему всем действом, Кариссима, если родит, должна принести свою жизнь в жертву ребенку, уступить место новой танцовщице. Она соглашается на это ужасное условие, и служанки выносят ее труп, танцем выражая скорбь. Но вдруг труп оживает и танцует. Молодой муж в смятении: ведь мертвые не танцуют; но Маэстро отвечает ему, что мертвые русские балерины танцуют, и, растроганный, ложится вместо Кариссимы в гроб, а она и ее ребенок счастливо живут в скучной роскоши замка Вир. Пьеса шла в Колизее несколько недель и в 1926 г. была поставлена в театре «Савой» (37 показов). Пресса писала об авторе, который превзошел себя («Панч»), о «сочетании фантазии, иронии и юмора» («Таймс»), о музыке Бакса как шедевре, «достойном наслаждения сам по себе» (36, р. 24).

Барри не был балетоманом или русофилом. Идея пьесы исходила от Лидии Лопуховой - на нее произвели впечатление книги о Питере Пэне, и в письме она предложила Барри написать для нее пьесу. Они встретились, и весной 1919 г. он начал работу над трехактной комедией о необычной жизни русской балерины, прототипом которой была 26-летняя миниатюрная, энергичная, экстравагантная Лопухова с ее «птичьими движениями» и «зыбким английским» (36, р. 26). Сюжет пьесы оказался пророческим: в 1925 г. Лопухова вышла замуж за известного экономиста Мейнарда Кейнса, что (в 1942 г.) принесло ей титул леди Кейнс. Однако в июле 1919 г., когда пьеса была наполовину завершена, Лидия внезапно исчезла, оставив записку для Дягилева, что у нее нервный срыв. Пару месяцев никто не знал, что с ней (14, c. 375). Барри напрасно звонил ей, пораженный ее исчезновением и непредсказуемостью. Отсюда подзаголовок пьесы, датированный сентябрем 1920 г.: «Предупреждение в одном акте» (A Warning in One Act), хотя в окончательной версии пьесы его нет (Барри помирился с Лопуховой). Но в конце лета 1919 г. он решил написать другую, одноактную пьесу о русской балерине, не говорящей по-английски и исче- 
зающей (точнее, умирающей), завершил ее к концу 1919 г., переориентировав на Тамару Карсавину, с которой он был знаком через семью своего крестного сына (36, p. 27); Карсавина даже больше соответствовала образу Кариссимы (перекличка имен неслучайна): в 1915 г. в Петрограде она вышла замуж за Генри Брюса, атташе в британском посольстве, и в 1917 г. они с сыном бежали через Мурманск в Великобританию (14, p. 290). Пьеса Барри была ее первым балетмейстерским опытом, с чем ее поздравил Дягилев.

Основная в пьесе тема - общения русских и англичан - представлена как пародия на обе стороны. Русские танцоры - необычные, отличающиеся от принятой нормы люди, выражают себя в танце, их питает дух и «страсть искусства», что непонятно респектабельным традиционалистам - старшим Вирам. «Фантазия и красота, ассоциируемые с “русским началом” танцоров, противостоят строгости и банальности английской жизни, лишенной воображения» $(36$, р. 27). Это два разных мира.

Маэстро ассоциировался с Дягилевым. В пьесе упомянуты покровители дягилевских балетов - леди Эдвардс (Мися Серт-Эдвардс) и Эдди Марш. Русское происхождение Маэстро подтверждает то, что, как и балерины, он объясняется мимически, хотя в окончательной версии он обретает дар речи.

Барри воплотил в пьесе несколько шаржированное, но очень британское представление о мире русского балета, который ведет не поддающуюся здравому смыслу таинственную жизнь; оторванный от внешней среды, он подобен эксклюзивному британскому клубу с определенным числом пожизненных членов, где кто-то должен умереть, чтобы освободить место другому (10, р. 29).

О. Соболева противоречит себе. Заявляя, что Барри постиг суть «русского мифа», она замечает, что в русских танцорах было мало «русскости»: завораживающие и экзотичные, они едва ли представляли свою страну, ее традицию, ее идентичность, а Стравинский в своих балетах, как утверждали критики, откликнулся скорее на модернистское и космополитическое, чем национальное и фольклорное, в «Bесне священной» он «использовал литовские и славянские обряды в независимой манере, которую можно назвать кубистской» (36, р. 28). Так же интерпретируются постановки Дягилева начала 1920-х годов. О. Соболева исходит из того, что Дягилев и его танцоры отвергли как 50 
устаревший императорский балет, так и советскую культуру, и упрощает феномен русской культуры и Дягилева. Он шел от русского Серебряного века, от эстетических идеалов «Мира искусства» с его идеями «новой красоты»; он вывез в Европу высшие достижения русской музыки, балета, декорационной живописи Серебряного века, представив миру вдохновенную живопись Бакста, Бенуа, Рериха и новаторскую хореографию. Само преклонение перед «бессловесностью» хореографического театра органично связано с символистскими идеями начала века о непознаваемых «таинствах духа» (5, с. 79). Для Дягилева балет это «целый мир», ведущий к гармонии, красоте, смыслу, «которые недоступны даже драме» (3, с. 121). Он представил Западу не только новую эстетику балета, но - шире - эстетику нового искусства в триединстве музыки - балета-живописи. Дягилева и его коллег питала разноликая, но единая эстетическая революция в России и Европе. Он потому так живо и принял живопись французского авангарда, что ему был близок русский авангард (Гончарова, Ларионов, недаром позднее он сблизился с Маяковским в Париже).

Казалось бы, далекий от балета и России Барри (что приближает его к среднему британскому зрителю той поры), эдвардианец, т.е. человек домодернистского поколения, обладал тем не менее замечательной художественной интуицией и показал в своей пьесе, что яркая, непосредственная, эмоциональная, порой неистовая русская традиция (Кариссима) - это мощная инъекция, способная омолодить строгий консерватизм британской жизни; «в этой стране, как замечает Маэстро, нет склонности и чувства к искусству» (10, р. 29). Брак молодой пары - Кариссимы и лорда Вира представлен как позитивный путь, недаром ребенок говорит на языке «русской стороны». В «русском начале» Барри ощутил проявление «другого» как отход от прежних, но еще господствующих викторианских ценностей, атаку на них эстетическими и этическими средствами (36, р. 30); его пьеса изображала контраст между необычным, «другим» началом русских танцоров и отсутствием творческой искры, конформизмом английской элиты, подтверждая сложившееся у британцев представление о русском народе как «более страстном», естественном, чем англичане (это мнение Вирджиния Вулф записала в своем дневнике 9 марта 1926 г.). Барри оказались близки идеи Роджера Фрая, художника и искусствоведа из группы «Блумсбери», писавшего о «невероятном различии между 
русской и западноевропейской ментальностью» (17, p. 35-36). Балет Дягилева подрывал понятие британской «нормы». «Русское» работало как линза, позволяющая увидеть «подлинное» и «реальное», скрытое глубоко в подсознании.

$$
* * *
$$

Сложен механизм культурного взаимодействия. В труппе Дягилева преобладали русские танцоры, но нередко он приглашал английских и ирландских танцоров, по его условию обычно выступавших под русскими именами. Лидия Соколова (Хильда Маннингс) с 1915 г. в составе Русского балета (37, р. 68-69). В 1920-е годы в труппу поступили 14-летняя Алисия Маркс - Алисия Маркова (14, p. 446), Вера Кларк - Савина, Нинетт де Валуа, Руперт Дун и др. Антон Долин (ирландец Патрик Кей) и Маркова стали ведущими танцовщиками (14, p. 387, 389, 414, 508, 577), что позволило королю Георгу выдать желаемое за действительное и сказать во время дягилевского спектакля 24 июля 1929 г. королю Египта Фуаду, что тот, конечно, знает о «британских танцорах - Соколовой, Долине и балет по-настоящему английский, а не русский» $(9$, р. 221-222). Но балет был русский, хотя в его недрах созревали британские плоды.

История современного балета в Англии началась с освоения идей и форм «нового балета», предложенных «Русскими сезонами». После распада труппы Дягилева из-за его смерти в 1929 г. в Британии остались высокопрофессиональные танцоры, прошедшие «школу Дягилева» и стремившиеся к созданию национального балета. Его «крестной матерью» называют Нинет де Валуа, в 1931 г. она основала труппу Vic-Wells Ballet, переименованную в Сэдлерс Уэллс (Sadler's Wells), с 1957 г. ставшую Королевским балетом Великобритании. Маркова и Долин создали балетную труппу Марковой - Долина (1935-1949) основу Английского национального балета; в 1950-1962 гг. Долин был его художественным руководителем, Маркова стала первой британской балериной, удостоенной титула Prima Balerina Assoluta. Мари Рамбер, с 1910 г. работавшая у Дягилева и помогавшая Нижинскому ставить «Весну священную», в 1920 г. открыла в Лондоне балетную школу, а в 1930 г. создала балетную труппу «Rambert Dance Company», где спектакли ставили знаменитые в будущем хореографы Энтони Тюдор и Фредерик Эштон, который учился у Леонида Мясина. 
Английскому балету для обретения своего лица необходимо было преодолеть мощное дягилевское влияние. Поэтому в начале 1930-х годов некоторые авторы книг о балете в Англии пытались умалить последние творения Дягилева (21). А. Хаскелл в книге «Дягилев: Артистическая и личная жизнь» (20) назвал период 1922-1929 гг. «В поисках утраченной юности». Нинет де Валуа критиковала «неопределенную» природу дягилевской труппы, отсутствие у него учеников. Складывался миф об упадке «Русского балета», но время расставило все на свои места.

Британский балет, пройдя «русскую школу» и сохранив многое из того, что впервые появилось у Дягилева, конечно, был другим. Ставший широко известным балетный критик Ричард Бакл (1916-2001), редактор журнала «Балет» (Ballet, 1939, 1946-1953), автор книг о Дягилеве (1979), Нижинском (1971), Джордже Баланчине (с Джоном Тарасом, 1988), издавший автобиографию Лидии Соколовой, заметил: «Русские танцуют всем телом, а англичане - нет» (цит. по: 38). Вероятно, эта особенность «русской школы» находила высшее воплощение в Нижинском, о котором Оттолайн Моррелл заметила: «Он отдается танцу, не просто как хороший балетный танцор <..> он - само воплощение того, что передает в танце» (29, р. 226-227).

В наши дни в Британии сохраняется память о творчестве Дягилева. Шотландский писатель и журналист Эндрю О’Хаган назвал его «повелителем танца», менеджером чуда мирового масштаба, увидевшим в балете самое магическое из искусств, в котором сочетаются скульптура и пространство, музыка и движение, живопись, дизайн, эрос и танатос, создавшим культ балета и преобразовавшим все виды искусств в XX в. (30). На выставке 25 сентября 2010 - 9 января 2011 г. «Дягилев и золотой век Русского балета, 1909-1929») в Музее Виктории и Альберта в Лондоне, завершая триумфальное празднование столетия Ballets Russes, начавшееся в мире еще в 2009 г., Дягилев предстает как Художник - организатор и создатель красоты, неистовый, необузданный и величественный, возвышенный.

Созвучие Дягилева, его труппы, его искусства и английской культуры было относительным, ибо налицо два разных типа культурной ментальности. Теоретически невозможное культурное созвучие между ними практически оказалось возможным, но лишь до определенной 
степени, что не помешало Дягилеву войти в инонациональный Пантеон британской культуры.

\section{Список литературы}

1. Григорьев С.Л. Балет Дягилева. - М.: Изд-во «АРТ», 1993. - 383 с.

2. Красовская В. Русский балетный театр начала ХХ в. - Л.: Искусство, 1971. Кн. 1. $-526 \mathrm{c}$.

3. Лифарь С. Дягилев и с Дягилевым. - Париж: Дом книги, 1939. - 509 с.

4. Нестьев И. Жизнь Сергея Прокофьева. - М., 1973. - 713 с.

5. Нестьев И.В. Дягилев и музыкальный театр XX века. - М.: Музыка, 1994. $224 \mathrm{c}$.

6. Сергей Дягилев и русское искусство: В 2 т. / Сост. И. Зилберштейн, В. Самков. М.: Изобразительное искусство, 1982. - Т. 1. - 493 с.; Т. 2. -574 с.

7. Сурии Е.Я. «Русский балет» Сергея Дягилева и мировая хореография XX века // Сергей Дягилев и художественная культура XIX-XX вв.: Материалы первых Дягилевских чтений. 17-19 апреля 1987 г. Пермь. - Пермь: Пермское книжное изд-во, 1989. C. $167-175$.

8. Шаляпин Ф. Литературное наследство. Письма: В 3 т. / Ред., сост., авт. вступ. ст. Е. Грошева. - М.: Искусство, 1976-1979. - Т. 1. - 760 с.; Т. 2. - 408 с.

9. Acton H. Memoirs of an Aesthete. - L.: Methuen, 1948. - 415 p.

10. Barrie J.M. The Truth about the Russian Dancers / With an introd. by Karsavina T. // Dance Perspectives. - N.Y., 1962. - P. 4-30.

11. Beecham T. A mingled chime: Leaves from an Autobiography. - L.: White Lion, 1973. $-192 \mathrm{p}$.

12. Benson E.F. As we were; A Victorian Peep-show. - L.: Longmans, 1930. - 307 p.

13. Beaumont C. The Diaghilev ballet in London. - L.: Putnam, 1940. -355 p.

14. Buckle R. Diaghilev. - L.: A Hamish Hamilton Paperback, 1984. - 616 p.

15. Dukelsky V. Passport to Paris. - Boston: Little, Brown, 1955. - 502 p.

16. Eliot T.S. London letter // The Dial. - N.Y., 1921. - October. - P. 452.

17. Fry R. Russian icon-painting from a Western-European point of view // Masterpieces of Russian painting: Twentycolour plates and forty-three monochrome reproductions of Russian icons and frescoes from the XI to the XIII centuries / Ed. M. Farbman. - M.; L., 1930. - P. 35-58.

18. Garafola L. Diaghilev's Ballets Russes. - N.Y.: Oxford univ. press, 1989. -524 p.

19. Goossens E. Overture and beginners. - L.: Methuen, 1951. - 327 p.

20. Haskell A. Diaghileff: his artistic and private life. - L.: Victor Gollanz, 1936.$382 \mathrm{p}$.

21. Haskell A. Ballet Russe. The Age of Diaghilev. - L.: Weidenfeld \& Nicolson, 1968. - $127 \mathrm{p}$.

22. Kochno B. Diaghilev and the Ballets Russes / Transl. by A. Foulke. - L.: Allen Lane: Penguin press, 1971. $-274 \mathrm{p}$.

23. Lifar S. Serge Diaghilev. - L.: Putnam, 1940. - 556 p. 
24. Macdonald N. Diaghilev Observed by Critics in England and the United States. N.Y.; L.: Dance Horizons \& Dance Books, 1975. - 400 p.

25. Mackrell J. Bloomsbury Balerina: Lydia Lopokova. - L.: Weidenfeld \& Nicolson, 2008. - 404 p.

26. Marsh E. A Number of People. A book of reminiscences. - L.: Heinemann/Hamish Hamilton, 1939. $-420 \mathrm{p}$.

27. Massine L. My life in ballet / Ed. by Hartnoll Ph., Rubens R. - L.: Macmillan, 1968. $-318 \mathrm{p}$.

28. May R. The Translator in the text: On reading Russian literature in English. Evanston, Ill.: Northwestern univ. press, 1994. - 203 p.

29. Morrell $O$. The Early Memoirs of Lady Ottoline Morrell / Ed. by R. GathorneHardy. - L.: Faber, 1963. - 308 p.

30. O'Hagan A. Diaghilev: Lord of the dance // The Guardian. - 2010. - 9 Oct. - Mode of access: https://www.theguardian.com/.../2010/oct/.../diaghilev-ballets (Date of access 13.07.2018)*.

31. Pritchard J. Diaghilev and the Ballets Russes 1909-1929. - L.: V\&A Publishing, 2015. -240 p.

32. Propert W.A. Russian ballet in Western Europe, 1909-1920. - L.: John Lane, 1921. $-131 \mathrm{p}$.

33. Ricketts Ch. Self Portrait / Ed. by Cecil Lewis. - L.: Peter Davies, 1939. - 306 p.

34. Shead R. Constant Lambert. - L.: Simon Publications, 1973. - 160 p.

35. Sitwell O. Great Morning. - L.: Macmillan, 1948. - 324 p.

36. Sobolev O.J.M. Barrie and the ballets russes // International Journal of Comparative Literature \& Translation Studies. - Footscray, Vic., 2016. - N 4 (1). - P. 23-31.

37. Sokolova L. Dancing for Diaghilev / Ed. by Buckle R. - L.: Murray, 1960. - 287 p.

38. Strong R. Richard Buckle // The Guardian.-2001. - 13 Oct. - Mode of access: https://www.theguardian.com/news/.../guardianobituaries2 (Date of access: 25.06.2018).

39. Williams R. The Politics of modernism: Against the New Conformists. - L.: Verso, 1989. $-208 \mathrm{p}$.

40. Whitworth G. The Art of Nijinsky. - L.: Chatto \& Windus, 1913. $-152 \mathrm{p}$.

41. Woolf V. The essays of Virginia / Ed. McNeillie A. - L., 1988. - Vol. 3. - 551 p.

\section{References}

1. Grigor'ev S.L. Balet Dyagileva. - M.: Izd-vo «ART», 1993. - 383 s. $526 \mathrm{~s}$

2. Krasovskaya V. Russkij baletnyj teatr nachala XX v. - L.: Iskusstvo, 1971. - Kn. 1. -

3. Lifar' S. Dyagilev i s Dyagilevym. - Parizh: Dom knigi, 1939. - 509 s.

4. Nest'ev I. Zhizn' Sergeya Prokof'eva. - M., 1973. - 713 s.

5. Nest'ev I.V. Dyagilev i muzykal'nyj teatr XX veka. - M.: Muzyka, 1994. - $224 \mathrm{~s}$.

* Дата обращения для всех адресов электронных публикаций - 2018. 
6. Sergej Dyagilev i russkoe iskusstvo: V 2-h t. / Sost. I. Zilbershtejn, V. Samkov M. Izobrazitelnoe iskusstvo, 1982. - T. 1. - 493 s.; T. 2. - 574 s.

7. Suric E. Ya. «Russkij balet» Sergeya Dyagileva i mirovaya horeografiya XX veka // Sergej Dyagilev i hudozhestvennaya kul'tura XIX - XX vv. Materialy pervyh dyagilevskih chtenij. 17-19 aprelya 1987 g. Perm'. - Perm': Permskoe knizhnoe izd-vo, 1989. - S. 167175 .

8. Shalyapin F. Literaturnoe nasledstvo. Pis'ma: V 3 t. / Red., sost., avt. vstup. st. E. Grosheva. - M.: Iskusstvo, 1976-1979. - T. 1. - 760 s.; T. 2. - 408 s.

9. Acton H. Memoirs of an Aesthete. - L.: Methuen, 1948. -415 p.

10. Barrie J.M. The Truth about the Russian Dancers, with an introd. By Karsavina T. // Dance Perspectives. - N.Y., 1962. - P. 4-30.

11. Beecham T. A mingled chime: Leaves from an Autobiography. - L.: White Lion, 1973. - $192 \mathrm{p}$.

12. Benson E.F. As we were; A Victorian Peep-show. - L.: Longmans, 1930. - 307 p.

13. Beaumont $C$. The Diaghilev ballet in London. - L., 1940. -355 p.

14. Buckle R. Diaghilev. - L.: A Hamish Hamilton Paperback, 1984. - 616 p.

15. Dukelsky V. Passport to Paris. - Boston: Little, Brown, 1955. -502 p.

16. Eliot T.S. London letter // The Dial. - N.Y., 1921. - October. - P. 452.

17. Fry R. Russian icon-painting from a Western-European point of view // Masterpieces of Russian painting: Twentycolour plates and forty-three monochrome reproductions of Russian icons and frescoes from the XI to the XIII centuries / Ed. M. Farbman. - M.; L., 1930. - P. 35-58.

18. Garafola L. Diaghilev's Ballets Russes. - N.Y.: Oxford univ. Press, 1989. - 524 p.

19. Goossens E. Overture and beginners. - L.: Methuen, 1951. -327 p.

20. Haskell A. Diaghileff: his artistic and private life. - L.: Victor Gollanz, 1936. $382 \mathrm{p}$.

21. Haskell A. Ballet Russe. The Age of Diaghilev. - L.: Weidenfeld \& Nicolson, 1968. -127 p.

22. Kochno B. Diaghilev and the Ballets Russes / Transl. by A. Foulke. - L.: Allen Lane/Penguin press, 1971. -274 p.

23. Lifar S. Serge Diaghilev. - L.: Putnam, 1940. - 556 p.

24. Macdonald N. Diaghilev Observed by Critics in England and the United States. New York \& L.: Dance Horizons \& Dance Books, 1975. - 400 p.

25. Mackrell J. Bloomsbury Balerina: Lydia Lopokova. - L.: Weidenfeld \& Nicolson, 2008. - 404 p.

26. Marsh E. A Number of People. A book of reminiscences. - L.: Heinemann / Hamish Hamilton, 1939. - 420 p.

27. Massine L. My life in ballet / Ed. by Hartnoll Ph., Rubens R. - L.: Macmillan, 1968. -318 p.

28. May R. The Translator in the text: On reading Russian literature in English. Evanston: Ill.: Northwestern univ. press, 1994. - P. 30-31.

29. Morrell O. The Early Memoirs of Lady Ottoline Morrell / Ed. by R. GathorneHardy. - L.: Faber, 1963. - 308 p. 
30. O'Hagan A. Diaghilev: Lord of the dance // The Guardian. - 2010. - 9 Oct. - Mode of access: https://www.theguardian.com/.../2010/oct/.../diaghilev-ballets (Date of access 13.07.2018).

31. Pritchard J. Diaghilev and the Ballets Russes 1909-1929. - L.: V\&A Publishing, 2015. $-240 \mathrm{p}$.

32. Propert W.A. Russian ballet in Western Europe, 1909-1920. - L.: John Lane, 1921. $-131 \mathrm{p}$.

33. Ricketts Ch. Self Portrait / Ed. by Cecil Lewis. - L.: Peter Davies, 1939. - 306 p.

34. Shead R. Constant Lambert. - L.: Simon Publications. 1973. - 160 p.

35. Sitwell O. Great Morning. - L.: Macmillan. 1948. - 324 p.

36. Sobolev O.J.M. Barrie and the ballets russes // International Journal of Comparative Literature \& Translation Studies. - Footscray, Vic., 2016. - N 4 (1). - P. 23-31.

37. Sokolova L. Dancing for Diaghilev / Ed. by Buckle R. - L.: Murray, 1960. - 287 p.

38. Strong R. Richard Buckle // The Guardian.-2001. - 13 Oct. - Mode of access: https://www.theguardian.com/news/.../guardianobituaries2 (Date of access: 25.06.2018.).

39. Williams R. The Politics of modernism: Against the New Conformists. - L.: Verso, 1989. -208 p.

40. Whitworth G. The Art of Nijinsky. - L.: Chatto \& Windus, 1913. - $152 \mathrm{p}$.

41. Woolf V. The essays of Virginia / Ed. McNeillie A. - L., 1988. - Vol. 3. - 551 p. 